\title{
USE OF PERSONAL COMPUTERS TO ENHANCE THE GEOTECHNICAL ENGINEERING EDUCATION
}

\author{
M. Zoghi', Ph.D.
}

\begin{abstract}
The integration of personal computers in teaching the geotechnical engineering courses including the soil mechanics and foundation design, as well as soil mechanics laboratory will be described herein. In addition, the potential use of microcomputers in undergraduate and graduate special projects as part of independent studies will be discussed.
\end{abstract}

\section{Introduction}

The undergraduate civil engineering students at the University of Dayton (UD) are required to take a three semester credit hours soil mechanics course along with a one-credit hour soil mechanics laboratory to accompany the lectures. There are a total of ten experiments which are conducted over the course of the semester. In addition, two dual-level advanced geotechnical courses are offered which can be taken by the undergraduate students to satisfy their civil engineering electives, or towards their graduate programs. These reference courses are the advanced soil mechanics and foundation design. Students have also the option of taking an independent study custom-designed course in lieu of either one of the two advanced courses. The principal objective of this paper is to outline the integration of personal computers in these courses. Furthermore, the role of personal computers in conducting research projects as partial fulfillment of independent study courses will be discussed as well. Specifically, several recent computer programs, developed by the students as part of their term projects, will be reviewed herein to demonstrate the significance of personal computers in geotechnical engineering education.

\section{Personal Computer Use at UD}

Prior to taking the above geotechnical courses, the students of civil engineering at UD take a number of computer courses. The incoming freshmen are first exposed to computer practices in the Introduction to Civil Engineering Course, CIE 101. At this point they are introduced to the computer facility which include several PC and workstation laboratories and learn how to use the electronic mail and word processing. In the following semester, they are required to take a computer drawing course in which they are taught the basics of descriptive geometry and various CAD packages. During the sophomore year, structured programming logic is reviewed in a course called CPS 132. Subsequently, the computer applications in civil engineering are covered as part of an introductory course titled civil engineering computation laboratory, CIE 220. In this course, other programming routines such as BASIC and spread sheet are covered. Also, the students are

1 AssociateProfessor of Civil Engineering, The University of Dayton, Ohio 45469-0243 
exposed to. MATHLAB and TK solver by solving relevant civil engineering and engineering mechanics problems. At the junior-level, additional computer usage is considered in a civil engineering numerical " analysis course whereby the students develop and execute their own computer programs as well as utilize several c-tied packages to solve numerical problems. Evidently, by the time the students enroll in the soil mechanics course and associated laboratory in the second semester of junior year, they have accumulated adequate computer skills.

\section{Geotechnical Engineering Courses}

It is believed that the three most significant fundamental soil properties which are used directly in design of foundations are the permeability, compressibility and shear strength. Thus, the introductory soil mechanics course is centered around these concepts. After a review of engineering geology, the soil composition and classification are discussed. General principles of compaction along with standard and modified compaction test specifications are presented next. Subsequently, the three main features of permeability, compressibility and shear strength are taken up for the greater part of semester. The remainder of the course deals with several applications of these concepts; namely, lateral earth pressure, bearing capacity, slope stability, and an overview of environmental geotechnology.

In soil mechanics laboratory, a total of ten experiments are conducted throughout the semester. Specifically, a series of experiments deals with soil classification and compaction. Then, permeability tests consisting the constant head and falling head tests; compressibility (consolidation) test; and shear strength tests employing the direct shear device, unconfined compression machine and triaxial apparatus are conducted.

Considering that soil is an important construction material and probably the most complex one, a thorough knowledge of it is essential to the graduates of civil engineering programs. Since for most students this is the only opportunity they have to learn the concepts, it is imperative that they perform as many key exercises as practicable to gain an "intuition" for the material characteristics. To that end, the indispensable role of personal computers in optimizing the course coverage and learning process of it becomes apparent.

Though students are required to develop and execute relevant computer routines in the various topics discussed above, they are cautioned with consequences of the "blackbox" approach. One remedy to this potential dilemma has been using the powerful capa)ilities of a host of microcomputer spread sheet programs such as Lotus 1-2-3 ${ }^{\mathrm{TM}}$, SuperCalc ${ }^{\mathrm{TM}}$, QuattroPro ${ }^{\mathrm{TM}}$, and Excel ${ }^{\mathrm{TM}}$. Accordingly, the spread sheet routine is easily learned and can be employed to program complex calculations without due consideration for the traditional input / output procedures required by other structured programmings. Furthermore, the blackbox approach is for the most part eliminated due to the interactive environment of spreadsheet templates. Once a problem is formulated in the form of a template, alternative results can be evaluated by merely changing one or more parameter values in a few cells. Students will gain an insight into the material characteristics and design implications by considering numerous "what if' conditions.

The subsequent courses such as the foundation design and advanced soil mechanics are also treated primarily the same as the introductory soil mechanics course as far as the computer utilization is concerned. Due to greater design contents of the advanced courses, the parametric study approach is of more significance. Finally, regarding the independent study cases, students can delve the problems at hand in much greater details than it is possible manually. 


\section{Computer Applications}

In accordance with the foregoing discussion, a series of spread sheet templates are generated to incorporate the weight-volume relationships, compaction density curves, and soil classification characteristics. The majority of effort, however, is expended on formulating spread sheet routines for the permeability, compressibility, and shear strength characteristics. For instance, a template is initially generated to compute and plot the vertical stress distributions due to overburden pressure as well as induced foundation loading. The concepts of effective stress, neutral stress and total stress are incorporated in this program. Once, the stress distribution are configured in a soil mass, the compressibility (or settlement) characteristics of soil is readily determined in a subsequent spread sheet template. Furthermore, the bearing capacity of shallow footings under different loading configuration and soil conditions are investigated by combining the former templates on stress distribution and settlement analysis with a new bearing capacity template. The bearing capacity factors and associated shape, depth, and inclination factors are also formulated in the reference program.

The experience with the above automation and other similar programs have been positive. It appears that the 'students using these programs, along with long hand calculations, gain a better insight by primarily varying several of the input parameter values and observing the end results either graphically or simply as a footing size, factor of safety, or settlement value. Similar experiences are gained in the laboratory whereby the students evaluate specific experimental results as well as other hypothetical values in the relevant spreadsheet templates they develop for each experiment.

In addition to the above usage of microcomputers in development of spreadsheet programs, they can be adapted for data acquisition in the soil mechanics laboratory. Indeed, the Civil Engineering Department at the University of Dayton is in the process of automating the equipment in the soil mechanics laboratory by utilizing microcomputer based system. The system will consist of a data acquisition unit including 32 input/output channels designed to interface with laboratory testing equipment. Commercially available software packages will be acquired to record and analyze test results. This will relieve the students from monotonous manual data collection and reduce the accretion of errors.

\section{Conclusions}

The use of microcomputer spreadsheets appears to be amenable to the solution of myriad of geotechnical problems. Due to the versatility these tools offer and the fact that they furnish an interactive environment, the prospect of "blackbox" approach may be eliminated. The students can enhance their knowledge of the material by primarily varying the input parameter values and instantly observe the outcome. Furthermore, the microcomputers are adapted in the soil mechanics laboratory to automate the equipment and controlled data acquisition. Both of these applications can provide similar benefits in other engineering courses and laboratory environments. 


\section{Bibliography $\ldots . .$.}

ETHIYAJEEVAKARUNA, W., and JEYAPALAN, J. K., "Geotechnical Analysis on Micro-computers," Proceedings of 4th National Conference on Microcomputers in Civil Engineering, Orlando, FL, November 1986, pp. 372-376.

LANE, J. H., "Microcomputer Choice for Engineering Education," Proceedings of 4th National Conference on Microcomputers in Civil Engineering, Orlando, FL, November 1986, pp. 216-221.

RODERCIK, G. L., "Instructional Software for Soil Mechanics," Proceedings of 4th National Conference on Microcomputers in Civil Engineering, Orlando, FL, November 1986, pp. 221-224.

SMITH, W. S., "Microcomputers for Data Acquisition and Analysis in Soil Testing Courses," Proceedings of 4th National Conference on Microcomputers in Civil Engineering, Orlando, FL, November 1986, pp. 303308.

WOLFF, T. F., "Spreadsheet Applications in Geotechnical Engineering,” PWS Publishing Co., Boston, MA, 1995.

YERETZIAN, Y. S., and ZOGHI, M., "Settlement Analysis of Multi-Footing Foundations on Layered Soils Using Microcomputers," Proceedings of 7th National Conference on Microcomputers in Civil Engineering, Orlando, FL, November 1989, pp. 92-97.

ZOGHI, M., AUXER, W. D., and BEACH, T. J., "Microcomputer Spreadsheet Application for Design of Precast Concrete Wingwalls," Proceedings of 9th National Conference on Microcomputers in Civil Engineering, Orlando, FL, November 1991, pp. 66-69.

ZOGHI, M., AUXER, W. D., and MCKENNA, T. J., "Microcomputer Stability Analysis for Landslides in Colluvium," Proceedings of 9th National Conference on Microcomputers in Civil Engineering, Orlando, FL, November 1991, pp. 81-86. 